\title{
Article \\ Reduction of Evapotranspiration in Microenvironment Conditions of Table Grape Vineyards Protected by Different Types of Plastic Covers
}

\author{
Laura de Palma ${ }^{1, *(\mathbb{D}}$, Giuliano Vox ${ }^{2}$, Evelia Schettini ${ }^{2}(\mathbb{D})$ and Vittorino Novello ${ }^{3, *(\mathbb{D})}$ \\ 1 Department of Science of Agriculture, Food, Natural Resources and Engineering (DAFNE), \\ University of Foggia, Via Napoli 25, 71122 Foggia, Italy \\ 2 Department of Agriculture and Environment Science (DiSAAT), University of Bari, Via Amendola 165/A, \\ 70126 Bari, Italy; giuliano.vox@uniba.it (G.V.); evelia.schettini@uniba.it (E.S.) \\ 3 Department of Agricultural, Forestry and Food Sciences (DISAFA), Largo P. Braccini 2, 10095 Grugliasco, Italy \\ * Correspondence: laura.depalma@unifg.it (L.d.P.); vittorino.novello@unito.it (V.N.)
}

check for updates

Citation: de Palma, L.; Vox, G.;

Schettini, E.; Novello, V. Reduction of Evapotranspiration in

Microenvironment Conditions of

Table Grape Vineyards Protected by

Different Types of Plastic Covers.

Agronomy 2022, 12, 600

https://doi.org/10.3390/

agronomy 12030600

Academic Editor: Peter Langridge

Received: 25 January 2022

Accepted: 21 February 2022

Published: 28 February 2022

Publisher's Note: MDPI stays neutral with regard to jurisdictional claims in published maps and institutional affiliations.

Copyright: (C) 2022 by the authors. Licensee MDPI, Basel, Switzerland. This article is an open access article distributed under the terms and conditions of the Creative Commons Attribution (CC BY) license (https:// creativecommons.org/licenses/by/ $4.0 /)$.

\begin{abstract}
Saving water is a major challenge to increase environmental sustainability, particularly in semi-arid regions where most table grapes are produced. Water use is driven by atmospheric demand, which combines effects of solar radiation (prominent factor), wind, air temperature and humidity. Covering table grapes with transparent plastics is spread in many regions. Covers lower incoming solar radiation and wind speed, changing air temperature and humidity. This study assessed the effects of two plastic covers on reference evapotranspiration $\left(\mathrm{ET}_{0}\right)$ in comparison to the open field. For two years, two vineyards (cv. Victoria) trained to overhead trellis systems (tendone) were covered with two transparent polyethylene sheets: an agrotextile fabric $(\mathrm{C})$, and a commercial film (S). The sheet spectrophotometric properties were analyzed and the radiometric coefficients calculated. Micrometeorological data were recorded in the covered vineyards and in a nearby uncovered one. $\mathrm{ET}_{0}$ was calculated for June and July using the simplified Penman-Monteith equation. The coefficient of transmissivity to total photosynthetic radiation, a proxy of net radiation, was $73 \%$ for cover $\mathrm{C}$ and $83 \%$ for cover $\mathrm{S}$. On average, $\mathrm{ET}_{0}$ decreased by $35 \%$ under cover $\mathrm{C}$ and $31 \%$ under cover $\mathrm{S}$. Hence, in addition to providing protection from external agents, covers represent a valid tool for saving water in table grape viticulture; nevertheless, their radiometric properties should be considered and optimized to better achieve this goal.
\end{abstract}

Keywords: $\mathrm{ET}_{0}$; sheet radiometric coefficients; transparent polyethylene sheets

\section{Introduction}

Saving water resources to cope with its scarcity is one of the major challenges for the sustainability of agriculture, which is the largest user of water worldwide with over $70 \%$ of total withdrawals. Current global warming increases water scarcity since it accentuates atmospheric water demand, namely evapotranspiration (ET), and summer drought frequency, causing yield loss, particularly in the semi-arid zones such as those in which most table grapes are produced. The consequences are directly reflected in the quantitative and qualitative characteristics of the grapes [1-4]. Italy is one of the major table grape producers and currently supplies about 1.1 million tons almost exclusively from its southern regions [5]. Grapevine cultivation in south Italy is exposed to a high drought risk during the flowering-veraison phenophase: for this period, it has been assessed the occurrence of a crop water stress index $\left(1-\mathrm{ET}_{\mathrm{actual}}: \mathrm{ET}_{\max }\right)$-higher than 0.5 , which leads to a potential yield loss rate of about 30-60\% [6].

Growing grapevine under protecting structures, such as plastic sheets and nets, is a possible tool for limiting water use driven by atmospheric demand [7], which related to the 
available amounts of solar radiation, wind speed, air temperature and humidity and to air turbulence features, all modified by plastic screens [8-12].

Covering table grape vineyards with transparent plastic sheets is a standard practice in south Italy. Three covering techniques have been adapted to different purposes: (i) "early covering", aimed at advancing berry ripening by advancing bud-break. For this purpose, after the chilling requirement is satisfied, the vineyard top and sides are wrapped with plastic sheets: the greenhouse effect generated inside the structure accelerates the accumulation of growing degree hours needed for sprouting. Around flowering, side sheets are wound up or removed to avoid overheating; (ii) "late covering", aimed at delaying harvest. With this technique, the top of the vineyard is covered with plastic sheets at the beginning of veraison to protect shoots and bunches from external agents, so as to reduce abiotic and biotic damages and prolong the healthy life of the grapes on the vine. Nevertheless, the screen reduces the incoming solar radiation and modifies its spectrum, thus it changes the energetic and microenvironment conditions slowing down the grape maturation process itself [13]; (iii) "after-sprouting covering", aimed at protecting shoot and bunches from external biotic and abiotic agents, without seeking early or late grape harvest. In this case, the top of the vineyard is covered with plastic sheets when all buds have already sprouted. The protection provided by the screen, primarily from rain and excess sunlight, reduces the attacks of pathogens and the amount of chemicals sprayed, and also improves the appearance of the berries. The top sheets of all types of coverings are removed or "closed" at the end of the growing season.

To be suitable for growing purposes, plastic sheets require certain radiometric properties. A high transmissivity to solar radiation $(200-2500 \mathrm{~nm})$ is a general prerequisite, and a high ability to transmit photosynthetic light $(400-700 \mathrm{~nm})$ is always desirable (ideally $100 \%$, realistically $80-90 \%$ ) for its positive effect on plant physiology. Differently, a high transmissivity to near infrared radiation $(760-3000 \mathrm{~nm})$ is suitable for advancing bud-break but not for other aims, since this radiative range does not have a direct influence on the plant physiology but, representing $50 \%$ of total incident energy [14], gives a great heating contribution [15]. Unfortunately, additives capable of blocking near infrared radiations are expensive or not very effective, therefore rarely used [16]. The cover ability to diffuse the incident solar radiation should be also considered: it allows the canopy to receive sufficient amount of light while reducing temperature peaks [17]. At the opposite side of the solar spectrum, the ultraviolet rays (320-400 nm) degrade plastic polymers, thus, anti-actinic compounds are added to the plastic mix [15]. Ultraviolet rays damage also nucleic acids, proteins and photosynthetic pigments, but stimulate the synthesis of carotenoids and phenols which have sun-protection and antioxidant properties; therefore, they improve fruit color and richness in bio-active compounds, especially in flavonoids of both red and white grape berries [18,19]. Therefore, screens should allow a good amount of UV rays to enter. Finally, for the "early covering" technique, a low transmissivity (20-60\%) to the heating terrestrial long infrared radiation is required in order to increase the greenhouse effect by reducing radiative thermal losses [15].

The radiometric properties of plastic screens exert a paramount influence on the microenvironment inside the structure, thus they affect evapotranspiration. Many studies refer to the influence of plastic cover on vineyard microclimate, vine physiology and grape quality [20-26], while a limited number of studies are focused on the effects of plastic coverings on evapotranspiration of table grape vineyards [9,27-29] and, moreover, no one considers possible effects of sheets having different radiometric properties. The first aim of the present work was to estimate, in the environmental conditions of south Italy, the reference evapotranspiration that occurs during the warmest summer months under plastic sheets that cover table grape vineyards, in comparison with an open field. The second aim was to test the influence of different types of plastic covers on the evaporative demand. The ultimate goal was to acquire information to be used as a starting point to better exploit the potential of these protective screens for saving water resources. 


\section{Materials and Methods}

The trial was carried out at a privately owned vineyard (Laporta Farm) located in Trinitapoli (BT province, Apulia region) $41^{\circ} 18^{\prime} 28.2^{\prime \prime} \mathrm{N}-16^{\circ} 00^{\prime} 50.1^{\prime \prime} \mathrm{E}$, altitude $66 \mathrm{~m}$ a.s.l. The area has a warm-temperate climate classified as Csa (hot and dry summer Mediterranean conditions) according to Köppen and Geiger (1936) [30]. The average temperature is $16.7^{\circ} \mathrm{C}$; the average rainfall is $566 \mathrm{~mm}$ with precipitations mainly concentrated in winter. Summer climatic conditions last from June to September. July and August are the hottest months (avg. max. temp. 29.6 and $30.0^{\circ} \mathrm{C}$ ) and the least rainy ones (22 and $20 \mathrm{~mm}$ ); July has the lowest air relative humidity $(57.83 \%)$ and the number of rainy days (3.5) (Table 1 ). The area totalizes about 2170 Growing Degree Days (IV region of the Winkler scale) [31,32].

The site involved in the trial is located on a soil unit resting on a substrate of terraced marine deposits. The soils are calcareous, have a scarcely stony surface, medium texture, good drainage, good depth and low presence of skeleton [33]; a common reference value for a fairly deep soil is $60-90 \mathrm{~cm}$, while a low presence of skeleton commonly refers to less than $5 \%$.

Table 1. General climate features of the trial area (avg. 1999-2019, Climate-Data.Org) [34].

\begin{tabular}{|c|c|c|c|c|c|c|c|c|c|c|c|c|}
\hline & Jan & Feb & Mar & Apr & May & Jun & Jul & Aug & Sep & Oct & Nov & Dec \\
\hline Mean Temp. $\left({ }^{\circ} \mathrm{C}\right)$ & 8.6 & 8.9 & 11.4 & 14.5 & 18.7 & 23.2 & 25.9 & 26 & 21.9 & 17.9 & 13.8 & 9.9 \\
\hline Avg. Min. Temp. $\left({ }^{\circ} \mathrm{C}\right)$ & 5.8 & 5.8 & 7.9 & 10.6 & 14.7 & 19 & 21.6 & 21.8 & 18.4 & 14.7 & 10.9 & 7.1 \\
\hline Avg. Max. Temp. $\left({ }^{\circ} \mathrm{C}\right)$ & 11.7 & 12.2 & 15.1 & 18.3 & 22.5 & 26.9 & 29.7 & 30 & 25.4 & 21.4 & 17 & 12.8 \\
\hline Rainfall (mm) & 58 & 53 & 56 & 52 & 36 & 29 & 22 & 20 & 52 & 60 & 64 & 64 \\
\hline Avg. Air RH (\%) & 75 & 72 & 71 & 70 & 67 & 62 & 58 & 60 & 66 & 73 & 74 & 75 \\
\hline Rainy days (n) & 7 & 7 & 6 & 7 & 5 & 4 & 3 & 3 & 6 & 6 & 6 & 8 \\
\hline Sunny hours (n) & 6.3 & 7.0 & 8.7 & 10.4 & 12.0 & 13.0 & 12.9 & 12.0 & 10.1 & 8.1 & 7.0 & 6.3 \\
\hline
\end{tabular}

In two consecutive years (2015 and 2016), two adjacent 1 hectare vineyards of 'Victoria' (Vitis vinifera L.) vines grafted onto '1103 Paulsen' rootstock were involved in the trial. 'Victoria' is one of the main seeded table grape varieties grown in the area. Another nearby vineyard of the cv. Victoria was not protected either by plastic sheets or by anti-hail nets. Vines were 5-6 year old, spaced at $2.4 \mathrm{~m} \times 2.4 \mathrm{~m}$ and trained to overhead trellis system (tendone) pruned to $2-3$ canes per vine ( 10 buds/cane). The standard viticultural practices adopted by the farm were applied in all the vineyards, including cluster thinning (to 1.5 bunch/shoot), leaf thinning (4 interventions), mineral nutrition (fertilizer units: $135 \mathrm{~N}, 57 \mathrm{P}_{2} \mathrm{O}_{5}, 115 \mathrm{~K}_{2} \mathrm{O}, 80 \mathrm{CaO}, 25 \mathrm{MgO}$ ) provided partly by soil distribution and partly by fertigation, and irrigation provided by sub-surface system $\left(2000 \mathrm{~m}^{3}\right.$ /year as total amount of annual delivered water). Biostimulants were also applied to counteract biotic and abiotic stresses [35]. Grapes under covers were harvested in the last ten days of July; harvest in open field started 15 days later. The vineyards achieved similar berry quality (berry weight about $11.5 \mathrm{~g}$, juice total soluble solids $16^{\circ}$ Brix, titratable acidity $3.4-3.8 \mathrm{~g} / \mathrm{L}$ ) and productivity (about $23.5 \mathrm{t} /$ ha as average of the two years).

The early covering technique was applied. In March, to October, the vineyards were protected by plastic sheets (Figure 1). 


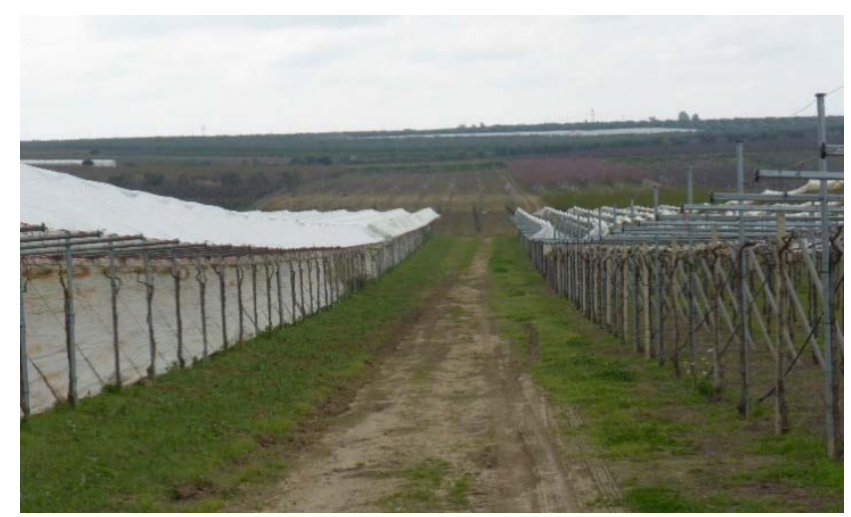

Figure 1. Adjacent vineyards protected with plastic sheets (left), uncovered vineyard (right) at the beginning of the second year of trial.

Plastic sheets that covered the vineyard sides were made of a not transparent lowcost woven fabric, according to the farm practice, while those that covered the top of the vineyards consisted of two types of plastic, one per vineyard, both made of $200 \mu \mathrm{m}$ thick low density polyethylene, transparent to solar radiation. They were (Figure 2): (i) cover C (Coverlys ${ }^{\circledR}$ agrotextile, $165 \mathrm{~g} / \mathrm{m}^{2}$, Beaulieu Technical Textiles, Comines-Warneton, Belgium), that was experimented for the first time on table grapes; (ii) Cover S (Serrosol film, $170 \mathrm{~g} / \mathrm{m}^{2}$, Serroplast, Rutigliano, BA, Italy), which was already renowned in the growing area. The former is totally recyclable, the latter is $60 \%$ recyclable. Both plastic materials were realized by adding classified compounds to improve their performance, especially as concerns thermal, anti-UV, antistatic, anti-drop effects. The covers and the vineyards were, respectively, labeled as $\mathrm{C}$ and $\mathrm{S}$.
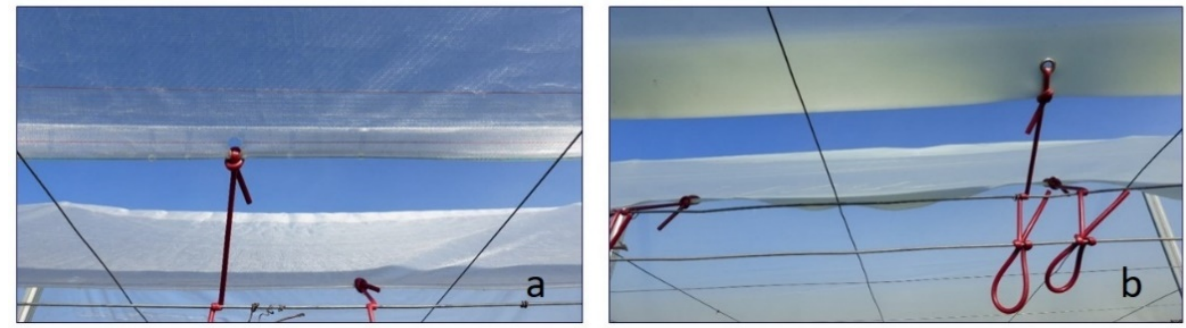

Figure 2. Polyethylene plastic sheets covering the top of vineyard C (Coverlys ${ }^{\circledR}$ agrotextile, (a)) and vineyard S (Serrosol film, (b)).

The spectroradiometric properties of the two plastic sheets were tested in the wavelength range of solar radiation (200-2500 $\mathrm{nm}$ ), photosynthetic active radiation (PAR, 400-700 nm), near infrared short radiation (NIR, 700-2500 nm), and Long Wave Infrared radiation (LWIR, 7500-12,500 nm) [17]. Briefly, direct transmissivity to solar radiation having perpendicular ray incidence was measured (10 nm step) using a UV VIS-NIR spectrophotometer (Lambda 950 Perkin Elmer, Waltham, MA, USA); total transmissivity was assessed by means of an integrating sphere; diffuse transmissivity was calculated as a difference between total and direct transmissivity. Transmissivity coefficients $(\tau)$ were calculated, according to Vox and Schettini (2007) [36], as weighted average values of spectral transmissivity. Transmissivity to LWIR was measured $\left(4 \mathrm{~cm}^{-1}\right.$ step), with direct perpendicular ray incidence, using a Perkin-Elmer FT-IR $1760 \mathrm{X}$ spectrophotometer; $\tau$ was calculated, according to Schettini and Vox (2012) [37], as average transmissivity. The samples were taken in four different positions of the top plastic sheets: two on the east-facing sheet side and two on the west-facing sheet side. For each position, five specimens $(50 \times 70 \mathrm{~mm})$ were tested. The radiometric coefficients were calculated using the average values of the measurements. 
In June and July, the hottest period before grape harvest, the side plastic sheets of the vineyards were removed to improve air circulation and reduce overheating, so vines remained covered only by the top plastic sheets (Figure 3 ).

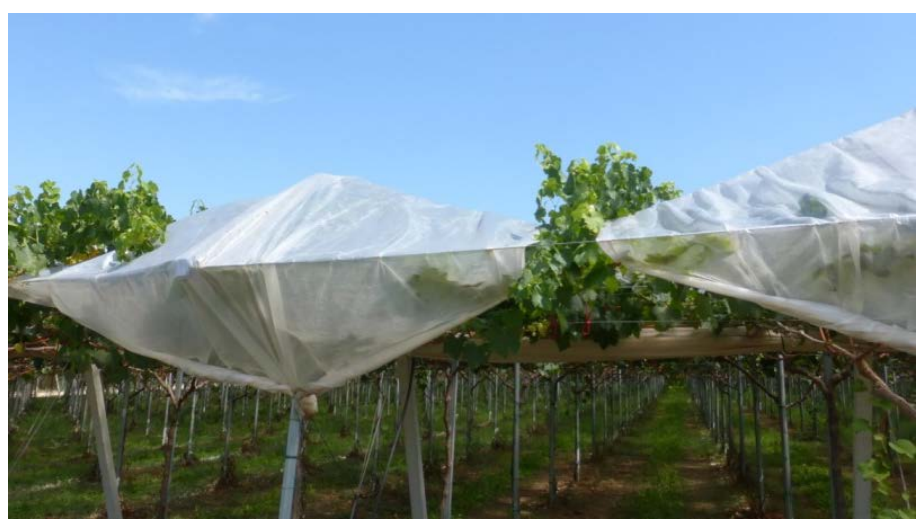

Figure 3. Vineyard after removing the side plastic sheets in order to improve air circulation and reduce overheating of air and vine organs.

The microenvironment conditions were monitored under the two covers and in the open air (2 stations per vineyard) as previously described [38]. Briefly, the following parameters were assessed at $2 \mathrm{~m}$ height: over-canopy photosynthetic photon flux (PPF), air temperature and relative humidity $(\mathrm{RH})$, and wind speed (Decagon Devices's sensors and data loggers); data were recorded at $15^{\prime}$ frequency. The reference evapotranspiration $\left(\mathrm{ET}_{0}\right)$ was estimated as standardized reference evapotranspiration $\left(\mathrm{ET}_{\mathrm{Sz}}\right.$, Equation (1)) using the Penman-Monteith simplified model according to indications of the Environmental and Water Resources Institute of the American Society of Civil Engineers:

$$
\mathrm{ET}_{\mathrm{sz}}=\frac{0.48 \Delta\left(R_{n}-\mathrm{G}\right)+\gamma \frac{C_{n}}{T+273} u_{2}\left(e_{s}-e_{a}\right)}{\Delta+\gamma\left(1+C_{d} u_{2}\right)}
$$

where $\Delta$ is the slope of saturation vapor pressure-temperature curve, $R_{n}$ is the net radiation, $\mathrm{G}$ is the soil heat flux density, $\gamma$ is the psychrometric constant, $C_{n}$ is the numerator constant (1600 for tall crops), $C_{d}$ is the denominator constant ( 0.38 for tall crops), $T$ is the mean daily air temperature at 1.5 to $2.5 \mathrm{~m}$ height, $u_{2}$ is the wind speed at $2 \mathrm{~m}$ height, $e_{S}$ is the saturation vapor pressure at 1.5 to $2.5 \mathrm{~m}$ height, $e_{a}$ is the mean saturation vapor pressure at 1.5 to $2.5 \mathrm{~m}$ height. All the parameters of Equation (1) that were not measured were calculated as suggested by ASCE-EWRI (2005) [39]. The net radiation, that is the main $\mathrm{ET}_{0}$ driving force [40-43], was derived from PAR values using Equation (2):

$$
R_{n}=\operatorname{PAR} \times 0.219 \times 0.0864
$$

Microenvironment data recorded under the coverings and in open field were downloaded using the ECH2O program. Daily and monthly average values were calculated, and graphs of daily average values were elaborated by means of the Statistical Analysis System version 9.4, SAS Institute, Cary, NC, USA. Standard errors were calculated for the monthly averages. Linear regressions between daily $\mathrm{ET}_{0}$ in open air and $\mathrm{ET}_{0}$ under each cover were obtained by applying the REG procedure and the PLOT procedure of the above mentioned statistical package.

\section{Results}

\subsection{Sheet Radiometric Properties}

The spectrophotometric analyses of the plastic covers highlighted their different radiometric properties (Figure 4). Cover $\mathrm{S}$ had more transmissivity to total and direct PAR ( $10 \%$ and $16 \%$ more, respectively), but lower diffusivity ( $6 \%$ less) than cover C (Table 2 ). 
Cover S showed also a greater transmissivity to the NIR range, either in terms of total radiation or, even more, in terms of direct radiation ( $8 \%$ and $20 \%$ more, respectively), but showed lower diffusivity ( $13 \%$ less). On the other hand, it resulted to have a higher transmissivity in the LWIR range, hence, during the night, was able to dissipate more heat than cover $\mathrm{C}$. The latter proved to have much greater transmissivity to UV radiations, i.e., almost double in terms of direct radiation and more than double in terms of total and diffuse radiation; however, this wavelength range has a negligible contribution to the thermal balance of plastic coverings.

Table 2. Radiometric coefficients of cover C (Coverlys ${ }^{\circledR}$ agrotextile) and cover S (Serrosol film).

\begin{tabular}{ccccccc}
\hline Wavelength Range & \multicolumn{5}{c}{ Transmissivity (\%) } \\
\hline & Total & Direct & Diffuse & Total & Direct & Diffuse \\
\hline & 75 & 48 & 27 & 82 & 64 & 17 \\
Total Solar (200-2500 nm) & 73 & 41 & 32 & 83 & 57 & 26 \\
PAR (400-700 nm) & 76 & 54 & 23 & 83 & 73 & 10 \\
NIR (700-2500 nm) & 68 & 29 & 38 & 30 & 15 & 15 \\
UV (280-380 nm) & & 27 & & & 58 & \\
LWIR (7500-12,500 nm) & & &
\end{tabular}
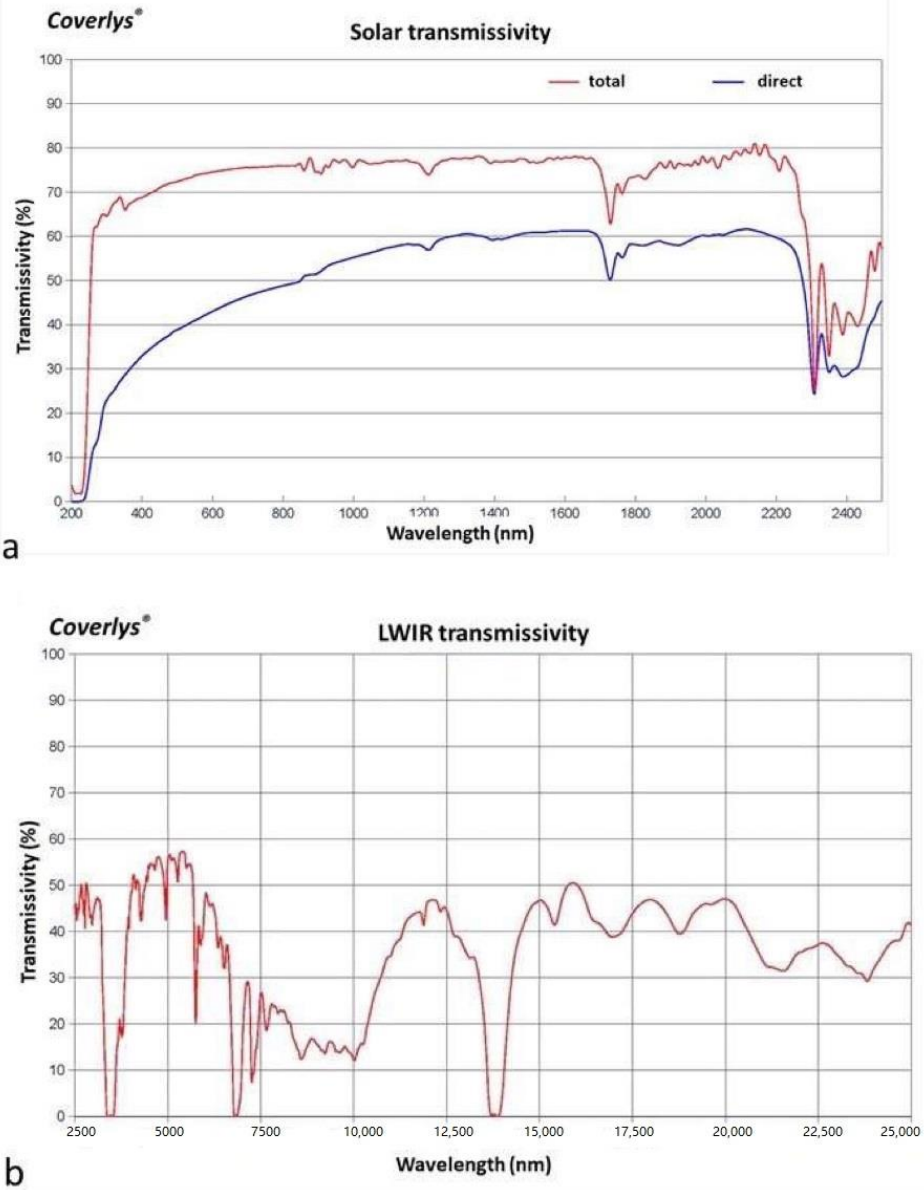

Figure 4. Cont. 

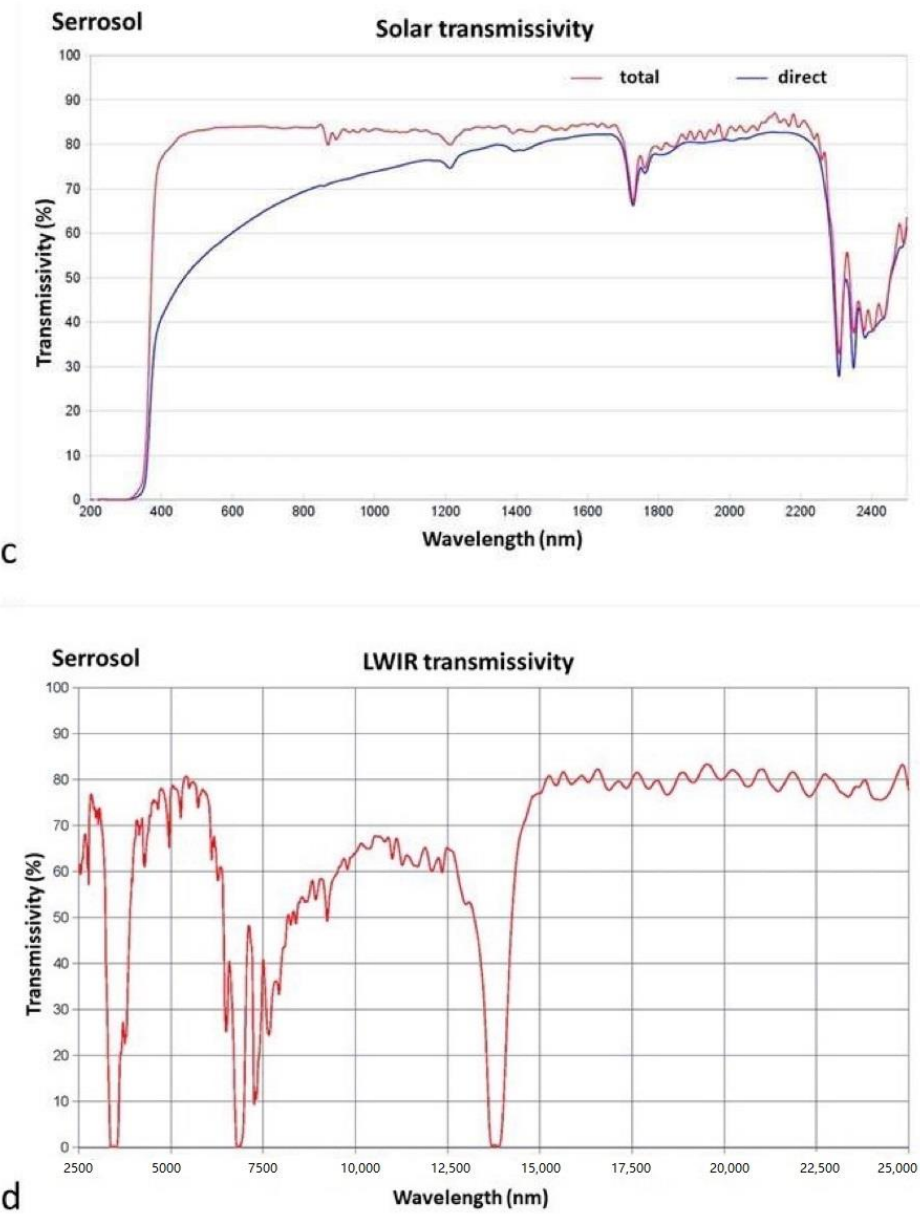

Figure 4. Total and direct spectral transmissivity to solar radiation (in the wavelength range 200-2500 nm) and to long infrared radiation (in the wavelength range 2500-25,000 nm) of cover C (Coverlys ${ }^{\circledR}$ agrotextyle, $\left.(\mathbf{a}, \mathbf{b})\right)$ and cover S (Serrosol film $(\mathbf{c}, \mathbf{d})$ ).

\subsection{Microenvironment Conditions}

\subsubsection{First Year of Trial}

Agrometeorological data recorded in the first year showed that the monthly average of daily photosynthetic photon flux in the open field was about $543 \pm 11.37 \mu \mathrm{mol} \mathrm{m}^{-2} \mathrm{~s}^{-1}$ in June and $664 \pm 8.52 \mu \mathrm{mol} \mathrm{m}^{-2} \mathrm{~s}^{-1}$ in July. The sheets induced a reduction of average PPF equal to $-29 \%$ (cover S) and $-31 \%$ (cover C) in June, and of $-35 \%$ (for both covers) in July. The patterns of PPF intercepted under the sheets followed that of values recorded in the open field (Figure 5). However, the difference of PPF available outside and under the sheets was not constant over time, since it was influenced by the sky conditions, being greater with clear skies. The irradiance intercepted under the two covers was quite similar: the biggest differences were around $16 \%$ in June and $6 \%$ in July; cover C showed a tendency for smaller values than cover $S$, as expected based on the radiometric properties of the two sheets. 

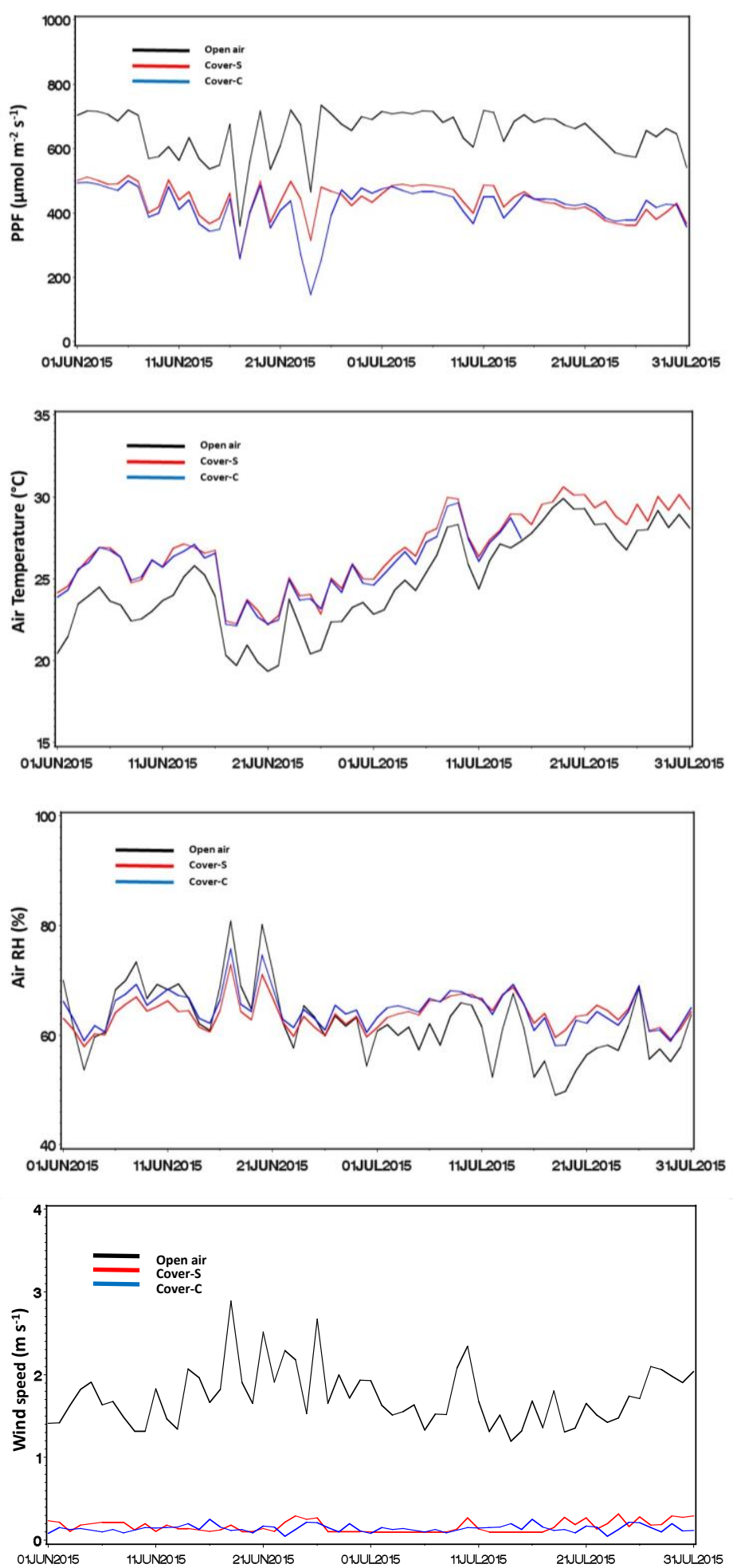

Figure 5. Course of average daily photosynthetic photon flux (PPF), air temperature, air relative humidity and wind speed recorded in June and July of the first year of trial, in open field and under plastic covers C (Coverlys ${ }^{\circledR}$ agrotextile) and S (Serrosol film). 
The monthly average of daily temperatures in the open air was $22.50 \pm 0.33{ }^{\circ} \mathrm{C}$ in June and $27.12 \pm 0.34{ }^{\circ} \mathrm{C}$ in July. The pattern of temperatures under the sheets followed that found in the open field, but reached higher values either in June $\left(1.5^{\circ} \mathrm{C}\right.$ to $3.5^{\circ} \mathrm{C}$ more $)$ or in July $\left(0.7^{\circ} \mathrm{C}\right.$ to $2.0^{\circ} \mathrm{C}$ more $)$. The air temperature under the two covers was very similar, with a slight tendency to higher values under cover $S$ : the maximum difference between the covers was $0.8^{\circ} \mathrm{C}$.

The monthly average of daily air relative humidity in the open field was $65.67 \pm 1.58 \%$ in June. The values recorded under the coverings sometimes coincided with those in the open air, but more often they were lower; the maximum decrement was about $-9 \%$ under cover $\mathrm{S}$ and $-4 \%$ under cover $\mathrm{C}$. In July, $\mathrm{RH}$ in open air felt to a mean value of about $59.0 \pm 0.87 \%$. Under the covers, the RH values incremented up to $+21 \%$.

The monthly average of daily wind speed in the open air were slightly greater in June $\left(1.82 \pm 0.07 \mathrm{~m} \mathrm{~s}^{-1}\right)$ than in July $\left(1.65 \pm 0.05 \mathrm{~m} \mathrm{~s}^{-1}\right)$. The covers induced a decrement of windiness by about $-90 \%$. Small differences were observed between the mean wind speed under cover $S\left(0.17 \pm 0.01 \mathrm{~m} \mathrm{~s}^{-1}\right)$ and cover $C\left(0.14 \pm 0.01 \mathrm{~m} \mathrm{~s}^{-1}\right)$.

\subsubsection{Second Year of Trial}

Agrometeorological data recorded in the second year (Figure 6) showed that the monthly average of daily PPF available in open air was about $519 \pm 15.92 \mu \mathrm{mol} \mathrm{m}^{-2} \mathrm{~s}^{-1}$ in June and $627 \pm 18.11 \mu \mathrm{mol} \mathrm{m} \mathrm{m}^{-2} \mathrm{~s}^{-1}$ in July, therefore, it was similar to that found in the previous year; also, the reduction of solar radiation passing through the sheets was very close to that previously found $(-30 \%$ with cover $C$ and $-38 \%$ with cover $S$, respect to open field).

The monthly average of the daily temperature outside the plastic sheets was $20.99 \pm 0.45{ }^{\circ} \mathrm{C}$ in June and $25.51 \pm 0.45{ }^{\circ} \mathrm{C}$ in July, which is about 2 degrees below that recorded in the first year. Plastic covers increased the air temperature up to about $2.5^{\circ} \mathrm{C}$ in June and $1.0^{\circ} \mathrm{C}$ July; a very slight tendency to higher values was noticed under the cover $\mathrm{S}$ respect to cover $\mathrm{C}\left(\max .+0.2{ }^{\circ} \mathrm{C}\right.$ in June and $+0.8{ }^{\circ} \mathrm{C}$ in July). Hence, all the trends that had emerged in the first year were confirmed.

The monthly average of daily RH in open air was $69.06 \pm 0.86 \%$ in June and $64.25 \pm 1.39 \%$ in July. Until mid-June, the plastic covers reduced RH with a maximum decrement of about $6 \%$ and $9 \%$ with cover $C$ and cover $S$, respectively, while they had the opposite effect for the next 45 days, as already observed in July of the first year.

The monthly average of daily wind speed was very close to that recorded in the same period of the previous year, either in open air $\left(1.84 \pm 0.09 \mathrm{~m} \mathrm{~s}^{-1}\right.$ in June, $1.82 \pm 0.10 \mathrm{~m} \mathrm{~s}^{-1}$ in July) or under cover $S\left(0.15-0.16 \pm 0.10 \mathrm{~m} \mathrm{~s}^{-1}\right.$ in June and July) and cover C $\left(0.14 \pm 0.01 \mathrm{~m} \mathrm{~s}^{-1}\right.$ in both months). Therefore, the reduction in windiness due to the plastic sheets was again about $-90 \%$. Wind speed was the parameter that manifested the greatest difference between the external and internal microenvironment.

\subsection{Estimated $E T_{0}$}

The monthly average of daily $\mathrm{ET}_{0}$ estimated in open air was about 4.6 and $4.1 \mathrm{~mm} \mathrm{~d}^{-1}$ in June of the first year and of the second year, respectively; in July, it increased, reaching about 5.1 and $4.7 \mathrm{~mm} \mathrm{~d}^{-1}$. The average daily $\mathrm{ET}_{0}$ under covers followed the same trends seen in open field (Figure 7), but, as presumable on the basis of the microenvironment data previously discussed, it was considerably lower: the effect of the plastic sheets was to reduce the monthly average of daily $\mathrm{ET}_{0}$ by $27-30 \%$ in June and $34-35 \%$ in July of the first year, and by $30-37 \%$ in June and $32-38 \%$ in July of the second year of trial.

The average values of daily $\mathrm{ET}_{0}$ estimated under the sheets were slightly lower for cover $C$ than for cover $S$ which had the greater total transmittance to PAR $(+10 \%)$ and to NIR (+8). The mean differences of daily $\mathrm{ET}_{0}$ between covers were minimal in the first year $(-4 \%$ in June and $-1 \%$ in July), greater in the second year $(-10 \%$ in June, $-9 \%$ in July). 

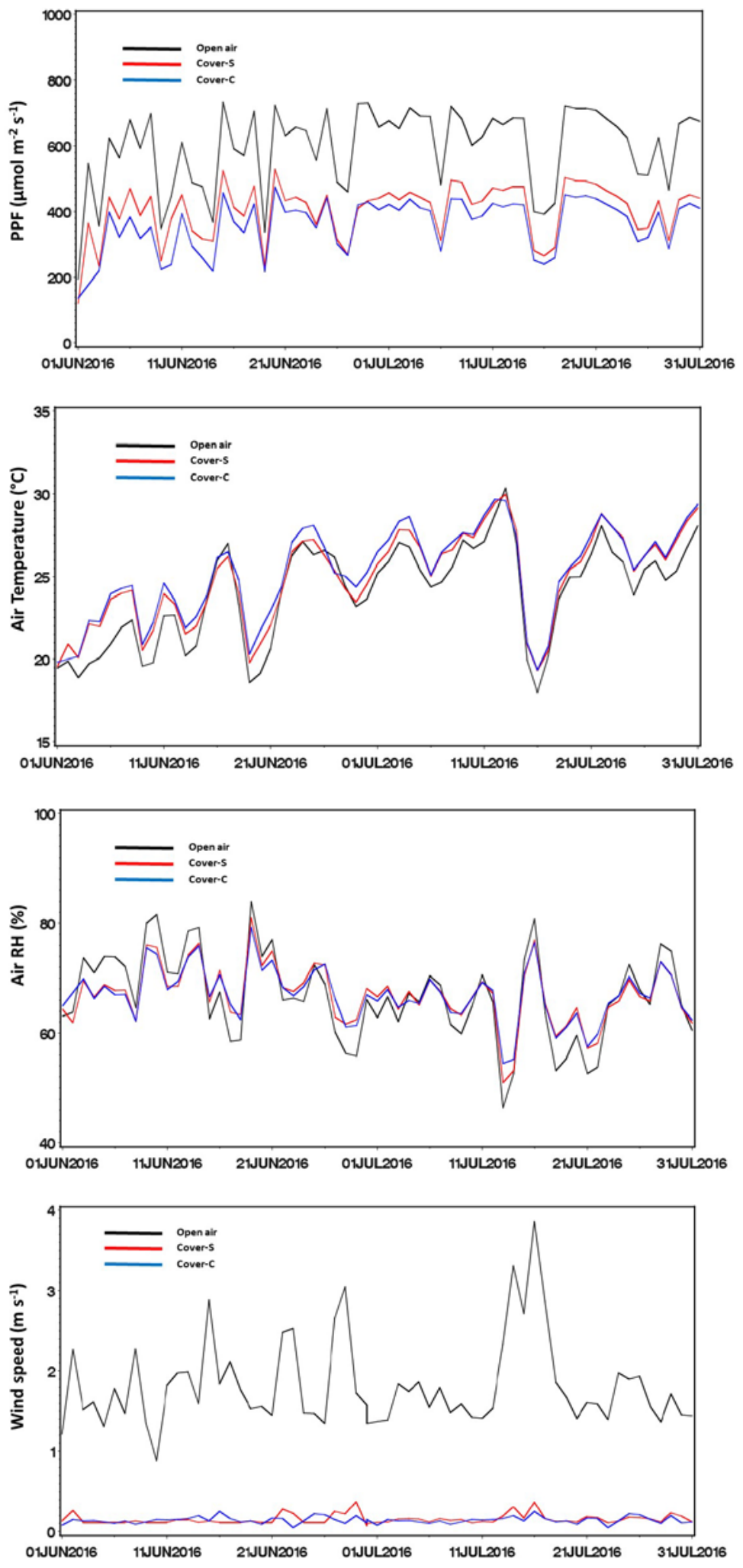

Figure 6. Course of average daily photosynthetic photon flux (PPF), air temperature, air relative humidity and wind speed recorded in June and July of the second year of trial, in open field and under plastic covers C (Coverlys ${ }^{\circledR}$ agrotextile) and S (Serrosol film). 

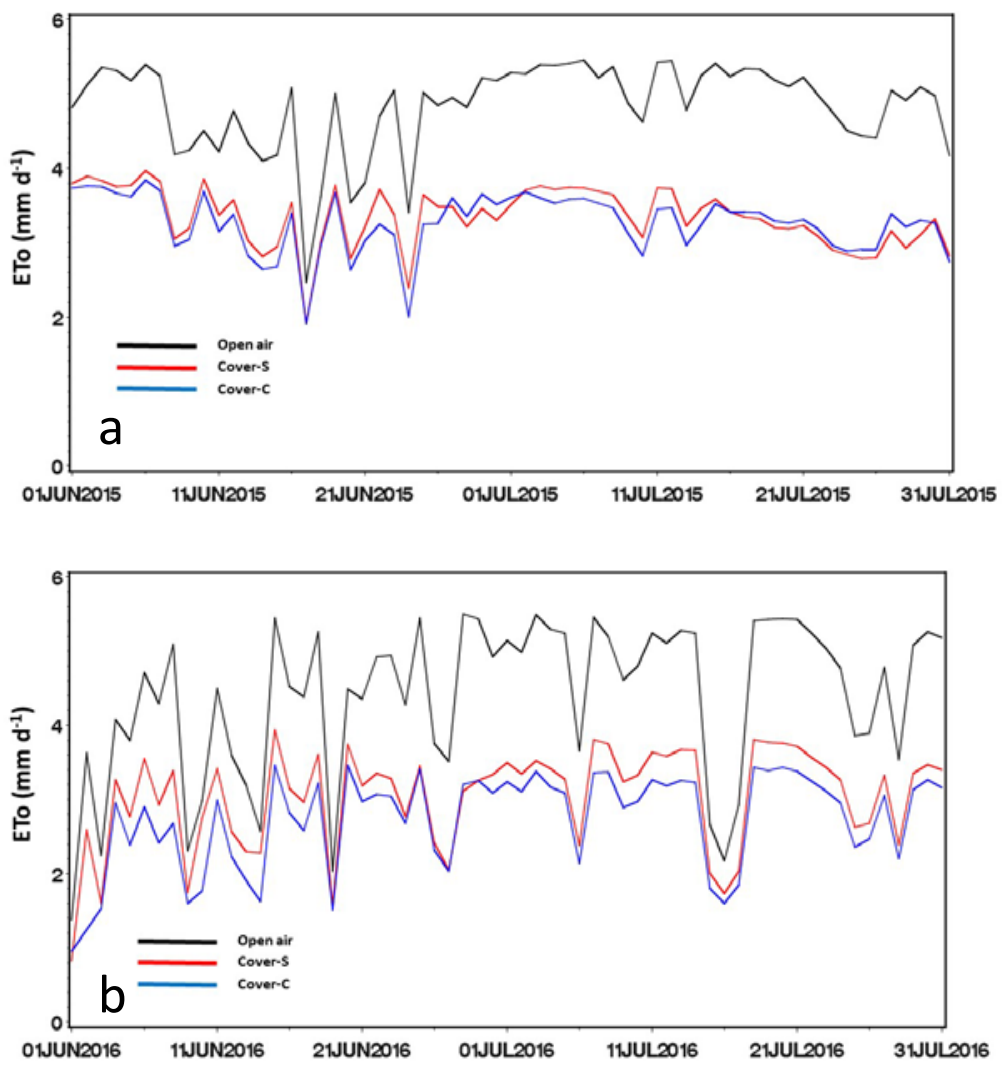

Figure 7. Course of average daily reference evapotranspiration $\left(\mathrm{ET}_{0}\right)$ estimated in June and July of the first (a) and the second (b) year of trial, in open field and under plastic covers C (Coverlys ${ }^{\circledR}$ agrotextile) and S (Serrosol film).

On a monthly basis, the $\mathrm{ET}_{0}$ cumulated in the open field in June and July was, respectively, about 138 and $157 \mathrm{~mm}$ in the first year and 122 and $147 \mathrm{~mm}$ in the second year (Table 3).

Table 3. Average data of daily and monthly $\mathrm{ET}_{0}$ estimated in open air and under plastic covers $\mathrm{C}$ (Coverlys ${ }^{\circledR}$ agrotextile) and S (Serrosol film) in the two years of trial.

\begin{tabular}{|c|c|c|c|c|}
\hline Month & Year & Cover & $\mathrm{ET}_{0}\left(\mathrm{~mm} \mathrm{~d}^{-1}\right)$ & $\mathrm{ET}_{0}\left(\mathrm{~mm} \mathrm{mo} \mathrm{m}^{-1}\right)$ \\
\hline \multirow{3}{*}{ June } & \multirow{3}{*}{$1 \mathrm{st}$} & Open air & $4.59 \pm 0.13$ & 137.64 \\
\hline & & Cover $S$ & $3.37 \pm 0.09$ & 100.96 \\
\hline & & Cover C & $3.23 \pm 0.09$ & 97.01 \\
\hline \multirow{3}{*}{ July } & \multirow{3}{*}{1 st } & Open air & $5.07 \pm 0.06$ & 157.21 \\
\hline & & Cover $S$ & $3.33 \pm 0.06$ & 103.10 \\
\hline & & Cover C & $3.29 \pm 0.05$ & 102.01 \\
\hline \multirow{3}{*}{ June } & \multirow{3}{*}{ 2nd } & Open air & $4.05 \pm 0.20$ & 121.56 \\
\hline & & Cover S & $2.84 \pm 0.13$ & 85.15 \\
\hline & & Cover C & $2.55 \pm 0.13$ & 74.06 \\
\hline \multirow{3}{*}{ July } & \multirow{3}{*}{ 2nd } & Open air & $4.73 \pm 0.16$ & 146.79 \\
\hline & & Cover S & $3.24 \pm 0.10$ & 100.43 \\
\hline & & Cover C & $2.95 \pm 0.09$ & 91.47 \\
\hline
\end{tabular}

The relationship between daily $\mathrm{ET}_{0}$ in open air and under cover $\mathrm{C}$ or cover $\mathrm{S}$ in June and July of the second year of trial (Figure 8) shows linear regressions with highly significant $\mathrm{R}^{2}$ for both covers. According to the angular coefficients of the regression lines, 
in this two-month period, the decrease of $\mathrm{ET}_{0}$ under cover $\mathrm{C}$ and cover $\mathrm{S}$ compared to the external environment was $58 \%$ and $61 \%$, respectively.

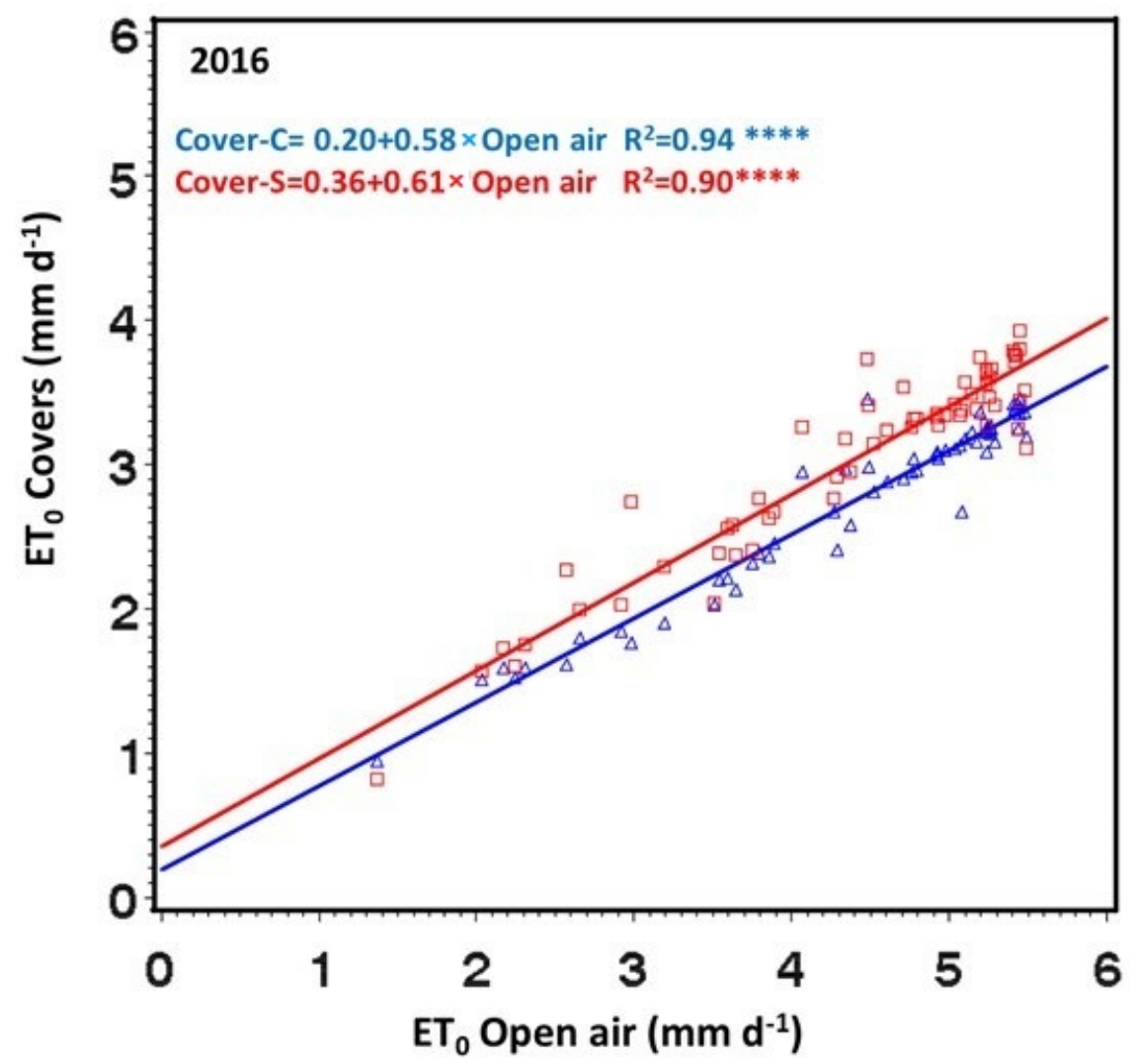

Figure 8. Linear regressions between daily reference evapotranspiration $\left(\mathrm{ET}_{0}\right)$ in open air and $\mathrm{ET}_{0}$ under cover C (Coverlys ${ }^{\circledR}$ agrotextile) or cover S (Serrosol film) in June and July of the second year of trial ${ }^{* * * *}$ indicates $\left.p<0.0001\right)$.

\section{Discussion}

Both covers, in terms of transmissivity to solar radiation, PAR and LWIR, showed the optimal characteristics required for crop protection and "precociation". According to the radiometric coefficients (Table 2), the theoretical reduction of total photosynthetic solar radiation could be expected at about $-17 \%$ with cover $S$ and $-27 \%$ with cover $C$. However, cover $S$ reduced the incoming PAR more than expected. This result could have been affected by several factors reported in the literature $[15,44]$, such as the degree of sheet tension and its resulting inclination with respect to sun's rays, the amount of dust and/or humidity retained by the sheet surface, the opacification of the plastic material caused by the sun radiation exposure, etc.

Plastic covers increase the air temperature with respect to open fields, as they limit the heat dispersion $[15,44]$. This effect was found to be greater in the relatively fresher month, which was June, than in the warmer one, namely July. Comparing the two covers, the tendency shown by the cover $S$ to induce slightly warmer air temperatures than cover $\mathrm{C}$ was evidently related to its higher transmissivity in the PAR and NIR wavelength ranges. However, since during all the test period the lateral sheets of the two coverings were open, the difference in air temperature between coverings was very little. The biggest differences occurred on days with very clear skies, i.e., when the direct component of solar radiation was high and therefore more heating.

The influence of the covers on air relative humidity changed over time. During most of June of the first year and during the first half of June of the second year, the RH inside the coverings was often lower than that in the open field, likely due to the higher thermal regime under cover. A generally opposite trend occurred in the remaining period of the 
trial, that is, when the differences between external and internal temperatures were smaller. In addition, it is to consider that, at that time of the season, the canopy of all the vineyards was fully expanded and, thus, the total amount of transpired water increased enriching the surrounding air with humidity which under the coverings was more retained, due to the scarce air movement that occurred in the protected environment.

The covers significantly slowed the wind speed inside the vineyard by acting as a physical barrier capable of extinguishing the gusts of air. Wind speed was the parameter that showed the greatest difference between the external and internal microenvironment in this trial. In addition to attenuating the wind speed near the crop, screens used for crop protection modify the characteristics of air turbulence and hence reduce the effect of the wind on the exchange of heat and water vapor between plant canopy and surrounding atmosphere [7].

The daily patterns of $\mathrm{ET}_{0}$ closely followed those of PAR, either in open field or inside the coverings (Figures 5 and 6). Overall, the plastic sheets reduced $\mathrm{ET}_{0}$ between 27\% (cover $\mathrm{S}$ in June) and 35\% (cover C in July) in the first year and between $30 \%$ (cover S in June) and 38\% (Cover C in June and July) in the second year. The range of these values is similar to that found by Cardoso et al. (2008) [25]. Therefore, plastic sheet coverings can give a significant contribution to the reduction of the atmospheric evaporative demand and, therefore, to the use of the water resource required by the table grape vineyard. The most pronounced differences between open air and protected environment occurred on days with clearer skies, warmer temperatures and lower relative humidity, while vice versa, the smaller differences occurred on cloudy days with relatively cooler temperatures and higher relative humidity, i.e., when the barrier effect exerted by the plastic sheets against incoming solar radiation was attenuated.

Cover C, which had the lower transmittance to PAR, NIR and total solar radiation, showed the tendency to induce lower $\mathrm{ET}_{0}$ compared to cover $\mathrm{S}$. Depending on the environmental conditions, the differences between the two types of plastic sheets were almost zero or reached $9 \%$, which is a value close to the difference between their coefficients of transmittance at PAR (10\%) and NIR (7\%).

The practice of growing fruit crops under plastic sheets is presently expanding and involves more crops, such as cherry, apple, kiwi, etc. These screens reliably transmit the spectral signals emitted by vegetation [45], so they do not hinder the application of the remote sensing techniques, which have also been implemented for monitoring evapotranspiration and enhancing the accuracy of input deliveries, and, thus, the sustainability of cultivation. It cannot be ignored that agricultural plastics are mostly derived from petrochemical sources; nevertheless, it is possible to provide their correct mapping, collection, disposal and recycling process at the end of the life cycle $[44,46,47]$, improving their environmental sustainability.

\section{Conclusions}

In the present study, both the tested plastic coverings modified the microclimate by exerting a barrier effect against the incoming solar energy and wind speed, reducing the reference evapotranspiration by $30-38 \%$ with respect to open field. ET $_{0}$ is known to be primarily affected by net radiation which, in this trial, had PAR as a reliable proxy. The inside air temperature and relative humidity variation, compared to the outside ones, had a lower effect on $\mathrm{ET}_{0}$ than net radiation.

In addition, this study showed that the specific radiometric properties of the two plastic sheets may influence the $\mathrm{ET}_{0}$ under coverings. In fact, the type of plastic sheet, with its different transmissivity to the wavelengths of the radiation spectrum, modulated the reduction of $\mathrm{ET}_{0}$ in the protected environment to a different extent. Therefore, aiming at maximizing the effect exerted by plastic coverings in reducing the evaporative demand, their radiometric properties should be also considered. 


\begin{abstract}
Author Contributions: Conceptualization, L.d.P. and V.N.; methodology, L.d.P., V.N., G.V. and E.S.; software, V.N., G.V. and E.S.; validation, L.d.P., V.N., G.V. and E.S.; formal analysis, L.d.P., V.N., G.V. and E.S.; investigation, L.d.P., V.N., G.V. and E.S.; resources, L.d.P., V.N., G.V. and E.S.; data curation, V.N. and G.V.; writing—original draft preparation, L.d.P. and V.N.; writing-review and editing, L.d.P., V.N., G.V. and E.S. All authors have read and agreed to the published version of the manuscript.

Funding: This research was partially supported by Beaulieu Technical Textiles (Comines-Warneton, Belgium), and partially carried out by means of staff and equipment made freeely available by the University of Foggia, University of Turin, OP Agritalia and University of Bari, in preparation for the Task 3.3 of the regional research project P.S.R. Puglia 2014/2020-Misura 16 Cooperazione-SM 16.2 "Sostegno a progetti pilota e allo sviluppo di nuovi prodotti, pratiche, processi e tecnologie". Avviso Pubblico approvato con D.A.G. n. 194 del 12/09/2018. Progetto "Uve Apirene pugliesi dal campo alla tavola: innovazione, nutrizione, sostenibilità"-Acronimo: "UVAPULIA"—DDS N. 94250037606 - CUP B49J20000130009. The first three partners are presently member of the GO (Operative Group) UVAPULIA.
\end{abstract}

Data Availability Statement: Not applicable.

Acknowledgments: The Authors thank Patrizio Limosani and Damiano Antoniciello (as fellows supported by the Giovanni Dalmasso Foundation of Turin) for their technical assistance, Laporta Farm for hosting the trial.

Conflicts of Interest: The authors declare no conflict of interest.

\title{
References
}

1. Medrano, H.; Tomás, M.; Martorell, S.; Escalona, J.-M.; Pou, A.; Fuentes, S.; Flexas, J.; Bota, J. Improving water use efficiency of vineyards in semi-arid regions. A review. Agron. Sustain. Dev. 2015, 35, 499-517. [CrossRef]

2. Mirás-Avalos, J.; Araujo, E. Optimization of Vineyard Water Management: Challenges, Strategies, and Perspectives. Water 2021, 13, 746. [CrossRef]

3. Van Leeuwen, C.; Destrac-Irvine, A.; Dubernet, M.; Duchêne, E.; Gowdy, M.; Marguerit, E.; Pieri, P.; Parker, A.; De Rességuier, L.; Ollat, N. An Update on the Impact of Climate Change in Viticulture and Potential Adaptations. Agronomy 2019, 9, 514. [CrossRef]

4. Cataldo, E.; Salvi, L.; Mattii, G.B. Effects of irrigation on ecophysiology, sugar content and thiol precursors (3-S-glutathionylhexan1-ol) on cv. Sauvignon Blanc. Plant Physiol. Biochem. 2021, 164, 247-259. [CrossRef] [PubMed]

5. OIV (International Organisation of Vine and Wine). Statistical Report on World Vitiviniculture. 2019. Available online: http: //www.oiv.int/public/medias / 6782/oiv-2019-statistical-report-on-world-vitiviniculture.pdf (accessed on 12 January 2021).

6. Yang, C.; Menz, C.; Fraga, H.; Costafreda-Aumedes, S.; Leolini, L.; Ramos, M.C.; Molitor, D.; van Leeuwen, C.; Santos, J.A. Assessing the grapevine crop water stress indicator over the flowering-veraison phase and the potential yield lose rate in important European wine regions. Agric. Water Manag. 2021, 261, 107349. [CrossRef]

7. OIV-International Organisation of Vine and Wine. Sustainable Use of Water in Winegrape Vineyards, 1st ed.; OIV Publications: Paris, France, 2021; ISBN 978-2-85038-023-5. Available online: https: / / www.oiv.int/en/viticulture/the-sustainable-use-of-water-inwinegrape-vineyards (accessed on 1 November 2021).

8. Novello, V.; de Palma, L.; Tarricone, L. Influence of girdling and plastic covering on leaf gas exchange, water potential and viticultural performance of table grape cv. Matilde. Vitis 1991, 38, 51-58.

9. Rana, G.; Katerji, N.; Introna, M.; Hammami, A. Microclimate and plant water relationship of the "overhead" table grape vineyard managed with three different covering techniques. Sci. Hortic. 2004, 102, 105-120. [CrossRef]

10. Teitel, M.; Wenger, E. The Effect of Screenhouse Roof Shape on the flow Patterns-Cfd simulations. Acta Hortic. 2012, 927, 603-610. [CrossRef]

11. Pirkner, M.; Dicken, U.; Tanny, J. Penman-Monteith approaches for estimating crop evapotranspiration in screenhouses-A case study with table-grape. Int. J. Biometeorol. 2014, 58, 725-737. [CrossRef] [PubMed]

12. De Almeida, L.V.B.; Rodrigues, W.; da Silva, J.R.; Figueiredo, F.A.M.M.D.A.; Deus, B.C.D.S.D.; Ruas, K.F.; Ferraz, T.M.; Martins, A.D.O.; Griffin, K.L.; Bressan-Smith, R.; et al. Transparent polyethylene covering film in tropical grapevines does not alter photosynthesis, plant growth, fruit quality or yield. Theor. Exp. Plant Physiol. 2020, 32, 255-270. [CrossRef]

13. Novello, V.; De Palma, L. Growing Grapes under cover. Acta Hortic. 2008, 785, 353-362. [CrossRef]

14. Duffie, J.A.; Beckman, W.A. Solar Engineering of Thermal Processes, 2nd ed.; Wiley: New York, NY, USA, 1980.

15. Papadakis, G.; Briassoulis, D.; Scarascia-Mugnozza, G.; Vox, G.; Feuilloley, P.; Stoffers, J. Review Paper (SE-Structures and Environment): Radiometric and Thermal Properties of, and Testing Methods for, Greenhouse Covering Materials. J. Agric. Eng. Res. 2000, 77, 7-38. [CrossRef]

16. Espí, E.; Salmerón, A.; Fontecha, A.; García, Y.; Real, A.I. PLastic Films for Agricultural Applications. J. Plast. Film Sheeting 2006, 22, 85-102. [CrossRef] 
17. Vox, G.; Schettini, E.; Scarascia Mugnozza, G.; Tarricone, L.; de Palma, L. Covering plastic films for vineyard protected cultivation. Acta Hortic. 2014, 1037, 897-904. [CrossRef]

18. Joubert, C.; Young, P.R.; Eyéghé-Bickong, H.A.; Vivier, M.A. Field-Grown Grapevine Berries Use Carotenoids and the Associated Xanthophyll Cycles to Acclimate to UV Exposure Differentially in High and Low Light (Shade) Conditions. Front. Plant Sci. 2016, 7, 786. [CrossRef]

19. Koyama, K.; Ikeda, H.; Poudel, P.; Goto-Yamamoto, N. Light quality affects flavonoid biosynthesis in young berries of Cabernet Sauvignon grape. Phytochemistry 2012, 78, 54-64. [CrossRef] [PubMed]

20. Çoban, H. Effects of Plastic Covering on Yield, Physical and Chemical Characteristics of Some Table Grapes (Vitis vinifera L.). Asian J. Chem. 2007, 19, 4052-4058.

21. Hernandes, J.L.; Júnior, M.J.P.; Blain, G.C.; Rolim, G.D.S. Comportamento produtivo da videira 'Niagara Rosada' em diferentes sistemas de condução, com e sem cobertura plástica, durante as safras de inverno e de verão. Rev. Bras. de Frutic. 2013, 35, 123-130. [CrossRef]

22. Tarricone, L.; Di Gennaro, D.; Amendolagine, A.; Notarangelo, L.; De Palma, L.; Vox, G.; Schettini, E. Effects of water regimes on vine performance and quality of 'sublima' seedless table grape covered with plastic film to advance grape ripening. Acta Hortic. 2014, 1038, 593-599. [CrossRef]

23. Deus, B.C.D.S.D.; Figueiredo, F.A.M.M.D.A.; De Almeida, L.V.B.; Ferraz, T.M.; Martins, A.O.; Rodrigues, W.P.; Viana, L.H.; Esteves, B.D.S.; Campostrini, E. Photosynthetic capacity of 'Niagara Rosada' grapes grown under transparent plastic covering. Ciência Rural 2016, 46, 950-956. [CrossRef]

24. Fidelibus, M.W.; Vasquez, S.J.; Kurtural, S.K. Late-season Plastic Canopy Covers Affect Canopy Microclimate and Fruit Quality of 'Autumn King' and 'Redglobe' Table Grapes. HortTechnology 2016, 26, 141-147. [CrossRef]

25. Holcman, E.; Sentelhas, P.C.; Conceição, M.A.F.; Couto, H.T.Z. Vineyard microclimate and yield under different plastic covers. Int. J. Biometeorol. 2017, 62, 925-937. [CrossRef] [PubMed]

26. Leitão, M.D.M.V.B.R.; De Azevedo, P.V.; Lima, P.C.D.S.; De Oliveira, G.M.; Dos Santos, C.A.C. Influence of Plastic Covering on the Microclimate in Vineyards in the São Francisco River Valley Region. Rev. Bras. Meteorol. 2017, 32, 399-407. [CrossRef]

27. Cardoso, L.S.; Bergamaschi, H.; Comiran, F.; Chavarria, G.; Marodin, G.A.B.; Dalmago, G.A. Alterações micrometeorológicas em vinhedos pelo uso de coberturas de plástico. Pesqui. Agropecuária Bras. 2008, 23, 441-447. [CrossRef]

28. Monteiro, R.; Rusin, C.; Fagherazzi, A.; Monteiro, P. Irrigation and Fertigation Management on Table Grape Under Plastic Cover in Serra Gaucha Region. In Proceedings of the Anais do II Inovagri International Meeting-2014; INOVAGRI/INCT-EI/INCTSal: Fortaleza, Ceará, Brazil, 2014; pp. 730-738. Available online: http://www.bibliotekevirtual.org/index.php/2013-02-07-03-02-35/ simposios / 221-ii-inovagri-2014/1413-ii-inovagri-2014-a098.html (accessed on 23 January 2022).

29. Conceição, M.A.F.; De Souza, R.T.; Zeoli, J.D.J.S.; De Paula, M.V.B. Coeficiente de cultura (Kc) para videira com e sem cobertura vegetal no solo. Embrapa Uva E Vinho-Artig. Em Periódico Indexado 2018, 1, 234. [CrossRef]

30. Koppen, W. Das geographisca System der Klimate. In Handbuch der Klimatologie; Koppen, W., Geiger, G., Eds.; Gerbuder Borntraeger: Berlin, Germany, 1936; pp. 1-44.

31. Winkler, A.J.; Cook, J.A.; Kliewer, W.M.; Lider, L.A. General Viticulture; Univ. of California Press: Berkley, CA, USA, 1974.

32. Blanco-Ward, D.; Queijeiro, J.G.; Jones, G.V. Spatial climate variability and viticulture in the Miño River Valley of Spain. VITIS 2007, 46, 63. [CrossRef]

33. PTCP Piano di Coordinamento della Provincia di Foggia. Analisi Fisica Integrata del Territorio Della Provincia di Foggia. Available online: http:/ / territorio.provincia.foggia.it/sites/default/files/3\%20Analisi\%20fisica.pdf (accessed on 1 November 2021).

34. Climate-Data. Org. Clima: Puglia. Available online: https://it.climate-data.org/europa/italia/puglia-454/ (accessed on 1 November 2021).

35. Cataldo, E.; Fucile, M.; Mattii, G.B. Biostimulants in Viticulture: A Sustainable Approach against Biotic and Abiotic Stresses. Plants 2022, 11, 162. [CrossRef]

36. Vox, G.; Schettini, E. Evaluation of the radiometric properties of starch-based biodegradable films for crop protection. Polym. Test. 2007, 26, 639-651. [CrossRef]

37. Schettini, E.; Vox, G. Effects of Agrochemicals on the Radiometric Properties of Different ANTI-UV Stabilized eva plastic films. Acta Hortic. 2012, 956, 515-522. [CrossRef]

38. De Palma, L.; Limosani, P.; Vox, G.; Schettini, E.; Antoniciello, D.; LaPorta, F.; Brossé, V.; Novello, V. Technical properties of new agrotextile fabrics improving vineyard microclimate, table grape yield and quality. Acta Hortic. 2020, 1276, 271-278. [CrossRef]

39. Allen, R.G.; Walter, I.A.; Elliott, R.L.; Howell, T.A.; Itenfisu, D.; Jensen, M.E.; Snyder, R.L. (Eds.) The ASCE Standardized Ref-erence Evapotranspiration Equation; American Society of Civil Engineers: Reston, VA, USA, 2005. [CrossRef]

40. Dennehy, K.F.; McMahon, P.B. Microclimate and actual evapotranspiration in a humid coastal-plain environment. J. Hydrol. 1987, 93, 295-312. [CrossRef]

41. Williams, L.E. Grapevine water relations. In Raisin Production Manual; Christensen, L.P., Ed.; DANR Publications, University California: Oakland, CA, USA, 2000; pp. 121-126.

42. Gao, Y.; Long, D.; Li, Z. Estimation of daily actual evapotranspiration from remotely sensed data under complex terrain over the upper Chao river basin in North China. Int. J. Remote Sens. 2008, 29, 3295-3315. [CrossRef] 
43. Wang, Q.; Wang, J.; Zhao, Y.; Li, H.; Zhai, J.; Yu, Z.; Zhang, S. Reference evapotranspiration trends from 1980 to 2012 and their attribution to meteorological drivers in the three-river source region, China: Reference Evapotranspiration Trends and its Attribution Analysis. Int. J. Clim. 2016, 36, 3759-3769. [CrossRef]

44. Scarascia-Mugnozza, G.; Sica, C.; Russo, G. Plastic Materials in European Agriculture: Actual Use and perspectives. J. Agric. Eng. 2012, 42, 15-28. [CrossRef]

45. Borgogno-Mondino, E.; De Palma, L.; Novello, V. Investigating Sentinel 2 Multispectral Imagery Efficiency in Describing Spectral Response of Vineyards Covered with Plastic Sheets. Agronomy 2020, 10, 1909. [CrossRef]

46. Picuno, P.; Sica, C.; Laviano, R.; Dimitrijevic, A.; Scarascia-Mugnozza, G. Experimental tests and technical characteristics of regenerated films from agricultural plastics. Polym. Degrad. Stab. 2012, 97, 1654-1661. [CrossRef]

47. Blanco, I.; Loisi, R.V.; Sica, C.; Schettini, E.; Vox, G. Agricultural plastic waste mapping using GIS. A case study in Italy. Resour. Conserv. Recycl. 2018, 137, 229-242. [CrossRef] 